\title{
O BISPO PEDRO CASALDÁlIGA E SUA OPÇÃO PREFERENCIAL NA LUTA PELA TERRA NO NORTE ARAGUAIA
}

\author{
THE BISHOP PEDRO CASALDÁLIGA AND ITS PREFERENTIAL OPTION IN THE FIGHT
}

FOR LAND IN NORTH ARAGUAIA

Claudiney de Freitas Marinho

Mestre em Geografia (UFT)

Professor do Instituto Federal de Educação, Ciência e Tecnologia do Mato Grosso (IFMT)

E-mail:aaaaaaa@bbb.com

Delismar Palmeira Costa

Graduado em Geografia (UFT)

Mestrando em Geografia (UFT)

João Germano Rosinke

Graduado em Ciências Econômicas pela UNEMAT

Mestrando em Ensino pelo IFMT

Pró-reitor de Desenvolvimento Institucional do IFMT

Ubiranei de Freitas Marinho

Especialista em PROEJA (IFMT)

Professor do Instituto Federal de Educação, Ciência e Tecnologia do Mato Grosso (IFMT)

Resumo: O campesinato e as comunidades indígenas enquanto células sociais sempre se viram à mercê da estrutura dominante do modo de produção capitalista. Todavia, parte da Igreja Católica comprometida com as questões sociais conflitivas do campo, se engajou na luta de camponeses e indígenas pela posse de suas terras, seja por meio de atuações políticas ou através de atos práticos. Em virtude disto, o objetivo desse texto é mostrar o papel do Bispo Pedro Casaldáliga na luta pela terra na microrregião geográfica denominada Norte Araguaia, cuja delimitação e localização se dão no estado do Mato Grosso. Para tanto, foi realizada uma ampla investigação histórica/geográfica acerca da vida e atuação política e prática dessa figura memorável, o que também pressupôs uma revisão teórica da própria discussão do campesinato, bem como da Teologia da Libertação. O papel ativo de Pedro Casaldáliga marca na história deste território a ruptura das concepções católicas tradicionais e, certamente, fortaleceu em favor dos oprimidos da terra a luta de classe, a identidade camponesa e indígena, o pertencimento. Os resultados compreende a consolidação sucessiva - após o processo de redemocratização do Brasil - de um número expressivo de Projetos de Assentamento da Reforma Agrária.

Palavras-chave: Bispo Pedro Casaldáliga; Camponeses e indígenas; Norte Araguaia; Luta pela Terra; Teologia da Libertação.

Abstract: The peasantry and indigenous communities as social cells have always found themselves at the mercy of the dominant structure of the capitalist mode of production. However, part of the Catholic Church committed to the conflictive social issues of the countryside, engaged in the struggle of peasants and natives for the possession of their lands, either through political actions or through practical acts. As a result of this, the purpose of this text is to show the role of Bishop Pedro Casaldáliga in the struggle for land in the geographic 
microregion denominated Norte Araguaia, whose delimitation and location occur in the state of Mato Grosso. In order to do so, an ample historical / geographical investigation was carried out on the life and political and practical action of this memorable figure, which also presupposed a theoretical revision of the own discussion of peasantry, as well as Liberation Theology. The active role of Pedro Casaldáliga marks in the history of this territory the rupture of traditional Catholic conceptions and certainly strengthened in favor of the oppressed of the land the class struggle, peasant and indigenous identity, belonging. The results include the successive consolidation - after the process of redemocratization in Brazil - of an expressive number of Agrarian Reform Settlement Projects.

Keywords: Bishop Pedro Casaldáliga; Peasants and indigenous people; Norte Araguaia; Fight for the Earth; Liberation Theology.

\section{Introdução}

As questões agrárias são recorrentes na história brasileira haja vista o contexto de formação da estrutura fundiária nacional. A concentração de terras nas mãos de poucos remota ao período das Capitanias Hereditárias, ainda no século XVI; as marcas desse tempo são notáveis até hoje, pois a construção histórica posterior em nada alterou a forte concentração de terras nas mãos de uma minoria elitizada. Os conflitos inerentes a essa problemática residem na figura do camponês, do indígena, do quilombola e de outros sujeitos sociais, internos e externos, sobretudo por se tratarem de populações tradicionais e, quase sempre antecede à instituição do latifúndio.

O camponês posseiro, enquanto sujeito social sempre se viu à mercê da estrutura dominante do modo de produção capitalista. Todavia, desde a década de 1960 parte da Igreja Católica (bispos, padres, freiras, leigos) reconhecida como uma ala progressista, comprometida com as questões sociais conflitivas do campo, após rompimento da ala tradicional desta instituição com o regime ditatorial imposto pelos militares no Brasil se engajaram na luta pela terra em opção preferencial à luta dos camponeses e comunidades indígenas. Dessa forma, surgem figuras centrais como Bispo Pedro Casaldáliga, Pe. Gentel, Pe Canuto, Pe. Josimo, Irmã Irene, dentre outros, determinados a combater as injustiças e atuar efetivamente durante os conflitos pela terra de trabalho no Brasil.

Assim, o objetivo desse artigo é mostrar a atuação social, política, ideológica e religiosa do Bispo Pedro Casaldáliga na luta dos posseiros e indígenas pela terra no norte Araguaia, cuja localização se dá no estado do Mato Grosso. Para tanto, foi realizada uma ampla investigação histórica/geográfica acerca da vida e atuação política e prática dessa figura memorável, o que 
pressupôs uma revisão teórica da própria discussão do campesinato, bem como da Teologia da Libertação.

Para subsidiar um melhor entendimento cronológico da luta pela terra no território da Prelazia de São Félix do Araguaia este trabalho está subdividido em quatro seções: inicialmente trata-se da questão camponesa inserida na história agrária brasileira; em seguida será abordado a marcha dos posseiros e sua respectiva chegada no norte Araguaia; depois é contextualizado a chegada de Pedro Casaldáliga e de sua equipe pastoral na região, bem como a sua escolha pela luta ao lado dos camponeses posseiros e comunidades tradicionais indígenas; por fim analisase alguns dos principais conflitos agrários em que a atuação do Bispo se tornou imprescindível na luta pela terra no norte Araguaia. Algumas breves considerações "finalizam" a análise aqui exposta.

\section{O camponês na história do Brasil}

O camponês se coloca como uma das classes sociais constituintes do modo de produção capitalista atual, isso é um fato indubitável. De acordo com a história que chegou até os dias atuais, pode-se atestar a sua existência em outros modos de produção além do capitalismo inicialmente citado. Suas ações sempre estiveram e estão ligadas a terra, pois a reprodução da vida material desta classe se funda primordialmente na agricultura, tendo como base o trabalho familiar. Assim, o campesinato é ator de sua própria história, uma classe que pode estar inserida nas mais diversas formações econômicas mundo a fora, no tempo e no espaço, devido ao seu caráter indiscutivelmente histórico.

Num país como o Brasil, o campesinato surge nas entranhas de uma formação social capitalista, cujas características eram atípicas às formas tradicionais de aparição dessa realidade na Europa; todavia a existência dessa "formação econômica-social capitalista", na colônia visava, acima de tudo, "maximizar a acumulação primitiva" (ANDRADE, 2004, p. 32). Evidentemente, o modelo de colonização adotado pelos portugueses em relação ao território brasileiro foi determinante para que as relações de trabalho não capitalistas se disseminassem. A colônia de exploração não tinha por finalidade o povoamento e a criação de uma sociedade moderna, espelho da metrópole; mas era senão uma forma de produzir imensas quantidades de produtos agrícolas e extrativos para que as receitas da metrópole fossem maximizadas por intermédio do mercantilismo vigente.

No Brasil, o primeiro modelo de apropriação efetiva do território se deu por meio da instituição das sesmarias, sobretudo devido ao advento das Capitanias Hereditárias, cujos 
donatários, responsáveis pelas parcelas doadas pela corte, poderiam eles mesmos distribuir as cartas de concessões a sujeitos que "atendessem a certas condições pré-estabelecidas", pois "Elas não eram confiadas a pessoas de poucos recursos, uma vez que o cultivo de terra, voltado para o mercado externo, exigia grandes somas para a compra de escravos e de ferramentas, e só a exploração de vastas extensões era lucrativa” (JAHNEL, 1987, p. 107). Assim, as sesmarias consistiam no direito de uso de uma parte do território por uma pessoa ou família delegada por uma autoridade competente, neste caso o guardião de um dos lotes hereditários; "Está, portanto, na velha instituição das sesmarias, a origem da propriedade imobiliária no Brasil" (BANDECCHI, 1963, p. 25).

O camponês brasileiro surge em meio a essa engenhosa formação social, que apesar do caráter capitalista se valia de relações de produção alheias ao seu modo de produção dominante. Em virtude disto, pode-se afirmar que o campesinato nacional "tem, na sua relação com o capital, contradições diferente daquelas que tem o operário", sobretudo no Brasil, "O camponês não é uma figura do passado, mas uma figura do presente da história capitalista do país" (MARTINS, 1995, p. 16). Diferentemente do campesinato europeu, cujas origens derivavam do modo de produção feudal, o camponês brasileiro é uma criação do próprio modo de produção capitalista.

No período colonial (1500-1822), após a proibição da escravidão indígena (1757), houve o processo de absorção desta parcela da população na grande propriedade sesmarial; dando origem à figura do agregado, um dos percussores do camponês atual. Portanto, após o fim desse regime de escravização, "o índio e o mestiço entraram para o rol dos agregados da fazenda", todavia, "excluídos do direito de propriedade, obrigados ao pagamento de tributos variados, desde serviços até gêneros, segundo a época, as circunstâncias e as condições do fazendeiro" (MARTINS, 1995, p. 32). O agregado foi senão o primeiro grande expoente do campesinato brasileiro.

Para Martins (1995, p. 32), havia também no interior da família aristocrática brasileira um sistema denominado morgadio, o "regime que tornava o primogênito herdeiro legal dos bens de um fazendeiro". Esse fato "veio engrossar e diferençar o campesinato durante o período colonial", pois essa prioridade fazia dos outros herdeiros "uma espécie de agregados do patrimônio herdado com base na primogenitura". Sabe-se que mais tarde, no império, o morgadio fora extinto; mais por motivos políticos do que por questões morais. Nesse processo, há um aumento significativo da massa daqueles que viriam mais à frente se tornarem os autênticos camponeses na formação econômica brasileira. O agregado se colocava dentro daquela estrutura como um ser social condicionado à existência do fazendeiro, ou seja, os seus 
direitos estavam garantidos na medida em que os interesses do fazendeiro fossem resguardados (MARTINS, 1995).

O camponês figurava-se como uma posse do senhor de terras, todavia, diferente daquela exercida sobre o escravo africano; de tal forma que pode-se afirmar que aquele campesinato era "duplamente excluído: da condição de proprietário de terras e da condição de escravo, já que não podia ser convertido em renda capitalizada do tráfico colonial” (MARTINS, 1995, p. 38). O camponês agregado tinha por papel principal a abertura de novas fazendas em extensões ainda não desbravadas, incumbia-se também da implantação dos cafezais, por exemplo, e como moeda de troca obtinha o direito de plantar gêneros de subsistência que precisasse; havia uma “exclusão, portanto, das relações de propriedade", o que por outro lado, "não o excluía da propriedade" (MARTINS, 1995, p. 38); mas o subjugava.

O próprio conflito existente dentro da fazenda fazia com que agregados fossem expulsos das parcelas senhoriais. Quem era enxotado não tinha outra escolha a não ser procurar terras ainda não utilizadas, para que o modo de vida camponês pudesse ser continuado; nesses novos territórios abria-se uma posse e restabelecia os aspectos culturais predominante do camponês "até que começassem a chegar os fazendeiros para abrir novas fazendas, quando então era preciso ir mais longe, buscar nova terra desocupada" (MARTINS, 1995, p. 111). O posseiro marcou esse movimento expansivo da civilização em direção às terras indígenas ainda não desbravadas. Esse camponês, de acordo com Martins (1995, p. 115), é "quem vive na fronteira da sociedade nacional, no limiar do mundo tribal". Assim,

intrusos e posseiros foram os precursores da pequena propriedade camponesa. A princípio, as invasões limitavam-se às terras de ninguém nos intervalos entre as sesmarias, depois orientaram-se para as sesmarias abandonadas ou não cultivadas; por fim, dirigiram-se para as terras devolutas e, não raramente, para as áreas internas dos latifúndios semi-explorados (GUIMAR ÃES, 2009, p. 51).

As contradições dessa realidade colocava o camponês como um migrante perene, além de um indigente político. Não havia quem o defendesse, por isso ele abria mão até mesmo de sua integridade física para mergulhar numa incessante luta pela terra; assim, pode-se afirmar que diferentemente das sesmarias, onde vigorava "primeiro o título, depois o trabalho", nas posses camponesas acontecia justamente o contrário: "primeiro o trabalho, depois o título" (BANDECCHI, 1963, p. 55). Em virtude dos fatos até aqui narrados, pode-se afirmar que a formação social do Brasil é marcada no período colonial por fortes contradições, sobretudo devido à questão da propriedade da terra, e em consequência também das relações de produção. 
O camponês "viveu durante todo o tempo do escravismo, essa contradição que só foi sanada quando se resolveu a contradição maior representada pelo escravo numa economia capitalista de produção escravista de mercadorias" (MARTINS, 1995, p. 38).

\section{A chegada dos posseiros no Norte Araguaia}

Para analisarmos esta conjuntura, de chegada dos posseiros no território desta pesquisa é preciso primeiramente reconhecermos a existência anterior de territórios ocupados por várias etnias indígenas, que encontravam em seus diferentes modos de vida, suas respectivas sobrevivências. Essa constatação é para Martins (2009, p. 9-10), uma situação de fronteira para aqueles que estão "do outro lado" que corresponde à limites de territórios que se redefinem continuamente, disputados de diferentes modos por diferentes grupos humanos e com interesses diferentes dos que estão do "lado de cá".

Dessa forma, Lima Filho (1998, p. 25), entende que a fronteira, ou seja, a frente de expansão da sociedade "civilizada" sobre territórios ocupados por povos indígenas no norte Araguaia iniciou ainda no ciclo das Bandeiras, do final do século XVI, o que abrange o período do Brasil Colônia. De acordo com suas pesquisas, este período foi denominado "Ciclo Paraubava" e, sua finalidade compreendia o aprisionamento de nativos e descoberta de minas de ouro. Esse mesmo autor descreve que em meados do século XVII surgi um novo momento da frente de expansão denominado "Ciclo Araguaia" em que pese não somente a busca de metais preciosos e aprisionamento de nativos, mas as missões catequéticas jesuítas.

Nestas investiduras algumas etnias indígenas permitiram o contato com as categorias emergentes, elucidadas em muitas literaturas como heróis e desbravadores. Outras se mantiveram praticamente isoladas até o início do século XX como a etnia Xavante e a etnia Kaiapó. Em razão deste comportamento divergente Casaldáliga (1971, p. 4) assevera que devido as particularidades distintas de cada etnia indígena, o contato com os não indígenas compreendeu uma relação individual e diferente. Os Xavante ${ }^{2}$ por exemplo eram reconhecidos

\footnotetext{
${ }^{1} \mathrm{O}$ rio Araguaia era conhecido pelos bandeirantes paulistas como Paraubava, alvo das bandeiras desde 1590. (LIMA FILHO, 1998, p. 25).

${ }^{2}$ Etnônimo é o nome que se aplica à denominação dos povos, das tribos, das castas ou de agrupamentos outros em que prevalece o conceito de etnia. Estes nomes utilizados na língua comum admitem a forma plural, como todos os outros: os brasileiros, os portugueses, os espanhóis, os botocudos, os tupis, os tamoios, etc.”. Entretanto, por convenção internacional de etnólogos, está há anos acertado que, em trabalhos científicos, os etnônimos que não sejam de origem vernácula ou nos quais não haja elementos vernáculos não são alterados na forma plural, sendo a flexão indicada pelo artigo plural: os tupi, os nambiquara, os caiuá, os tapirapé, os bântu, os somali, etc." (BRASIL. Fundação Nacional do Índio. - Brasília: Funai, 2016, p. 19)
} 
por serem caçadores, fortes e bravos; os Carajá por serem pescadores, comunicativos e artesãos; e, os Tapirapé não só pela pesca mas também por serem lavradores da terra.

Todas estas incursões que objetivavam desde a descoberta de riquezas minerais, a tomada de territórios e a submissão da força de trabalho indígena à condição de trabalho escravo, defrontou-se com a resistência e o enfrentamento dos povos tradicionais em defesa de suas terras. Tais ações de algumas aldeias indígenas no norte Araguaia, conforme aponta Lima Filho (1998, p. 27), asseguraram certo isolamento com a "sociedade nacional" até as últimas décadas do século XIX. Esta situação se mantêm até o início do século XX devido às sucessivas investidas de religiosos salesianos e de colonos, confabulando o que poderemos chamar de uma doutrinação da terra e dos povos da terra. Porém, tais ações resultaram em vários conflitos como emboscadas indígenas e mortes de inúmeros estranhos. Para ele (LIMA FILHO, 1998, p. 28) essas expedições muniam de notícias a mídia, que reforçava no imaginário nacional a ideia de uma região selvagem, exótica e distante.

Contudo, o que ideologicamente justificava a ocupação de "vazios demográficos" no território nacional, consiste na negação do outro, da sua existência e, certamente, justifica ao longo de décadas o extermínio de povos tradicionais para consolidação do projeto de expansão do modo capitalista de produção. A fronteira que outrora emergira no norte Araguaia, região nordeste do estado de Mato Grosso foi estimulada por um aglomerado de interesses de ordem econômica, política, social e ideológica, em que pese primeiramente a ampliação do capital no território nacional a partir da integração dos chamados "arquipélagos econômicos" e, em segundo plano, a busca de alternativas para amenizar os conflitos (principalmente agrários) concentrados nas regiões litorâneas do Brasil.

Os primeiros camponeses posseiros à compartilhar deste território com os povos indígenas de forma menos conflitiva foram migrantes oriundos principalmente da região nordeste do país, que chegaram nesta região no início do século $\mathrm{XX}$, incentivados pelas concepções milenaristas inspiradas nas profecias de padre Cícero sobre "a existência de um lugar mítico depois da travessia do grande rio [...]. Esse lugar mítico é reconhecido como o lugar das Bandeiras Verdes, que ninguém sabe dizer exatamente o que é nem onde é”. Seria, um lugar de refrigério, de águas abundantes, de terras livres, que contrasta com o nordeste árido e latifundiário, (MARTINS, 2014, p. 164).

Para Martins (2014, p. 164-165) estes movimentos migratórios são sempre lentos, com paradas demoradas ao longo de todo trajeto feito em grupos familiares e/ou de mesma localidade. Estes fenômenos vêm ocorrendo desde o início do século XX na direção LesteOeste correspondendo ao deslocamento de fronteiras e do movimento de efetiva ocupação do 
território, que mescla e adapta-se ao movimento próprio da frente de expansão. Nessa mesma tessitura, Ianni (1979, p. 12), apesar de tratar da política de colonização da Amazônia, colocada em prática pela ditadura militar a partir de 1964, descreve que esse movimento migratório inicial acontecia de forma espontânea e de certo modo, obedecendo a mesma direção descrita anteriormente, correspondendo um singular processo de colonização espontâneo. Em correspondente situação,

Santa Terezinha é o primeiro povoado habitado por não índios em toda região do Baixo Araguaia. Entre 1910 e 1915 chegam os primeiros sertanejos dispostos a ocupar estes "gerais". Em 1926, Santa Terezinha já tinha pequena Igreja. Em 1932 foram inaugurados os prédios da Igreja e da casa dos padres que ainda hoje existe sobre o Morro de Areia, marco expressivo da história desta região: junto a Igreja forma-se um pequeno povoado, (CASALDÁLIGA, 1997, p. 12).

O lugarejo Santa Terezinha do Araguaia, denominado primeiramente de Furo de Pedra, está localizado à margem esquerda do rio Araguaia, frente a Ilha do Bananal (porção de terras pertencente ao estado do Tocantins, antigo norte goiano) e com faixa de divisa com o sudeste do estado do Pará. A travessia do rio Araguaia compreendia a marcha da "Bandeira Verde", que foi se expandindo, nas primeiras décadas do século $\mathrm{XX}$, pelas terras de todo médio Araguaia no estado de Mato Grosso. Para Ianni (1979, p. 11) os posseiros chegavam na Amazônia vindo de diferentes lugares e ocupavam terras devolutas, tribais e latifundiárias.

[...] Uns vêm do Nordeste; outros do Sul. De todas as regiões do país vêm trabalhadores rurais e seus familiares para a Amazônia. Em muitos casos, chegam antes dos latifundiários, fazendeiros ou empresários, nacionais e estrangeiros. Outras vezes chegam juntos, misturados, todos buscando terra. Uns para plantar casa e roça e fazer criação; outros para formar fazendas de lavoura, gado, ou gado e lavoura; também aqueles que só querem a terra, a propriedade; e outros, que lidam com o comércio da terra: grileiros, jagunços, pistoleiros. Todos são migrantes, um para fazer negócios, outros por precisão. Às vezes mais, às vezes menos, estão sempre chegando, faz tempo, em muitos lugares, (IANNI, 1979, p. 11).

Concomitante ao deslocamento de posseiros para às proximidades do povoado de Santa Terezinha, o gradativo fluxo de navegações pelo rio Araguaia despertava interesses pelo uso das terras à margem esquerda deste rio, principalmente para criação de gado nas pastagens naturais formada por toda extensão de várzea do norte Araguaia. Assim, no final da década de 1930, camponeses da região Norte (principalmente do estado do Pará) e também da região Centro Oeste (norte goiano, atual estado do Tocantins e, de outras partes do estado do Mato Grosso) além de camponeses posseiros oriundos da marcha natural do Nordeste, deram 
continuidade ao processo de formação de outros povoados ribeirinhos como Mato Verde (atual município de Luciara) e Gariroba (atual município de São Félix do Araguaia).

Esta segunda etapa de deslocamento e fixação de camponeses e médios produtores para o norte Araguaia marcou uma peculiar diferenciação do fluxo migratório ocorrido em direção ao povoado de Santa Terezinha do Araguaia. Enquanto as primeiras migrações camponesas compreendiam um movimento exclusivo de posseiros e liderados por uma representação camponesa em busca das profecias da Bandeira Verde, ou seja, de terra de trabalho, os posteriores movimentos migratórios mesclavam posseiros e médios fazendeiros em regime de coronelismo, praticado no dispêndio do local de origem da migração. Temos a exemplo a figura emblemática do senhor Lúcio da Luz, coronel, fazendeiro do sudeste do estado do Pará que migrou com sua família e inúmeras famílias camponesas agregadas desta região e também do norte goiano, tornando-se o fundador do povoado Mato Verde, hoje Luciara. E, Severiano Neves, piauiense, tornou-se fazendeiro no Sul do Pará e migrou-se juntamente com o grupo de Lúcio da Luz. Desgarrou-se desse grupo e tornou-se fundador do povoado de Gariroba, hoje São Félix do Araguaia.

Por sua vez, a Igreja, sobretudo de doutrinação católica embreada de seu conservadorismo tradicional, assim como o próprio Estado sempre disseminaram apoio à classe dominante do país. As questões sociais estiveram alheias aos interesses destas instituições, principalmente em se tratar de interesses antagônicos pela bem maior que é a terra. Quaisquer que sejam as disputas de comunidades tradicionais e camponesas contra grileiros e latifundiários o apoio majoritário se materializava imediatamente em favor da classe dominante. Certamente é possível afirmar que uma parcela inexpressiva de representantes destas instituições não comungavam das arbitrárias decisões tomadas e praticadas. Para que estas vozes fossem minimamente ouvidas seria necessário o rompimento com a estrutura dominante em curso.

Somente no período da Ditadura Militar, a partir da publicação do Ato Institucional $\mathrm{n}^{\mathrm{o}}$ 5 e do "fechamento" do regime em 1968, o excesso dos militares promoveu, de certo modo, uma situação essencial para fragmentação de setores importantes da Igreja. Foi nesse contexto que os conservadores da Igreja Católica, ou seja, os mesmos defensores do regime militar no Brasil, que disseminavam o comunismo como a grande ameaça nacional, passaram, segundo Lowy (2016, p. 63) a conviver e evidenciar àqueles, cuja sensibilidade católica se diferenciava e, suas principais motivações consistiam na simpatia com a situação dos pobres e, que de certo modo eram atraídos pelo pensamento socialista e/ou comunista. Esta ala progressista apoiava os movimentos ditos "rebeldes" como movimento operário e ligas camponesas. Destacam-se a 
Juventude Universitária Católica (JUC), Juventude Operária Católica (JOC) e Movimento de Educação de Base (MEB), que objetivavam o desenvolvimento individual e coletivo dos indivíduos a partir da consciência crítica (ANGELOZZI, 2017, p. 67).

\section{A chegada de Pedro Casaldáliga e a opção da luta pela terra}

Pedro Maria Casaldáliga Plá é contemporâneo a esta parcela dita radical da Igreja. Nasceu no dia 16 de fevereiro de 1928 no povoado de Balsareny, na Catalunha, Espanha, onde foi seminarista e lá optou pela vocação sacerdotal missionária. Em 31 de maio de 1952, Pedro Casaldáliga foi ordenado padre em Barcelona e, posteriormente designado para Guiné na África com a finalidade de implantar cursos de cristandade. Deixando a África, Pedro trazia no seu imaginário o terceiro mundo, os pobres da terra e, essa nova Igreja, a "Igreja dos pobres", assim denominada mais tarde. E esse legado foi decisivo para tomada de decisão quando em 1967, em Assembleia, os Claretianos ${ }^{3}$ o designaram para "o anúncio da palavra como missão na Igreja" no nordeste mato-grossense. Ele tinha a permissão de sua congregação de fundar a missão Claretiana no território onde se consolidaria a Prelazia de São Félix do Araguaia.

Chegou ao Brasil em 26 de janeiro de 1968, permanecendo no Rio de Janeiro em um processo de formação e adaptação ao clima tropical desse país. Destinou-se a São Félix do Araguaia em 30 de julho de 1968, às vésperas da II Conferência do Episcopado LatinoAmericano em Medellín ocorrido em 08 de setembro de 1968, de onde fundamentou-se na sua caminhada. Segundo Barros apud Casaldáliga (2007, p. 3-4) nesta Conferência a Igreja LatinoAmericana estabeleceu a opção pelos pobres: "uma Igreja missionária e pascal... Pobre e despojada dos meios de poder... Uma Igreja, a serviço da libertação de toda a humanidade e de cada ser humano por inteiro..."

Segundo Lowy (2016, p. 73), a Teologia da Libertação e o Cristianismo da Libertação compreende um corpo de texto teológico produzido a partir de 1970 que expressa um vasto movimento social e religioso e, que envolveu setores significativos da Igreja (padres, ordens religiosas, bispos) e movimentos religiosos laicos (JUC, JOC, redes pastorais, CEBs, associações, camponeses, movimento das mulheres). Porém, esse movimento, ainda segundo o autor (LOWY, 2016, p. 80) não se disseminou por toda a Igreja. Influenciou apenas uma parcela

\footnotetext{
${ }^{3}$ Missionários Claretianos (ou formalmente Congregação dos Missionários Filhos do Imaculado Coração de Maria) são uma congregação religiosa católica fundada por Santo Antônio Maria Claret no dia 16 de julho de 1849 .
} 
das Igrejas latino-americanas, permanecendo a grande maioria à tendência predominante conservadora e/ou moderada. Adverte ainda que seu impacto estava longe de ser desprezível, especialmente no Brasil, onde a Conferência Nacional dos Bispos (CNBB), apesar de pressões insistentes do Vaticano, recuou-se a condená-la.

Para Lowy (2016, p. 80-81) a Igreja latino-americana deixava de se apresentar como uma corporação homogênea. E esta situação possibilitou a distinção de quatro correntes que emergira no interior da Igreja, sendo: uma poderosa corrente conservadora e tradicionalista; uma corrente reformista e moderada; uma minoria fundamentalista e ultrarreacionária; uma minoria radical e simpatizante da Teologia da Libertação. Tais distinções ajudam a compreender às orientações que Pedro Casaldáliga assumiu ao formar sua equipe pastoral em 1968. Lowy (2016, p. 81) afirma que o Bispo integrava a quarta tendência, representada por progressistas revolucionários solidários aos movimentos populares, de trabalhadores proletários e camponeses.

A chegada do missionário claretiano Pedro Casaldáliga e de sua equipe pastoral no norte Araguaia, em Mato Grosso assim como o compromisso destes com a realidade social vivida por toda população que encontrava-se neste território, foi certamente marcada por expectativas daqueles que disputavam diferentes interesses pela terra. Era sabido que índios, camponeses posseiros, peões, grileiros, jagunços, fazendeiros, comerciantes, dentre muitos outros segmentos sociais viviam em declarado conflito pelo bem maior, que é a terra. De um lado, os empreendedores agropecuários e grileiros, aliados ao Estado e a ala conservadora da Igreja Católica manifestavam interesse de mútua cooperação com toda equipe pastoral. Do outro lado, o outro segmento social, em condições de extrema vulnerabilidade (fome, expulsão, pauperização e êxodo) não tendo a quem recorrer senão à Igreja.

Segundo Casaldáliga (1971, p. 1) somente depois de três anos, após percorrer o território que se constituiria a Prelazia de São Félix do Araguaia, a equipe pastoral iniciou uma espécie de ruptura com o papel tradicional da Igreja e suas relações com o Estado e elites burguesas, aproximando-se de movimentos das classes oprimidas através das Comunidades Eclesiais de Base (CEBs). Para Casaldáliga (1971, p. 1) "a Igreja do Araguaia é também a Igreja da Amazônia e, origina-se dos oprimidos, da periferia”. Desta maneira, criou-se a Prelazia de São Félix do Araguaia no ano de 1970 e, fortaleceu-se um trabalho de luta em favor dos oprimidos e contra os opressores

esta Prelazia de São Félix, bem no coração do Brasil, abrange uns 150.000 $\mathrm{km}^{2}$ de extensão, dentro da Amazônia Legal, no nordeste do Mato Grosso, e com a Ilha do Bananal em Goiás. Esta encravada entre os rios Araguaia e 
Xingu e lhe faz como espigão dorsal, de Sul a Norte, a Serra do Roncador. O decreto de ereção da Prelazia, "Quo commodius", assinado por Paulo VI, aos 13 de março de 1970, define assim os limites estritos da Prelazia de São Félix: "ao norte os confins da Prelazia de Conceição do Araguaia, que atualmente delimitam os Estados do Para e do Mato Grosso; ao leste os confins da Prelazia de Cristalândia, e a oeste os da Prelazia de Diamantino, ou seja, os rios Araguaia e Xingu; ao sul a linha traçada em direção noroeste desde as confluências dos rios Curuá e das Mortes; e daí em linha reta até a confluência dos rios Couto de Magalhães e Xingu", (CASALDÁLIGA, 1971, p. 4).

Seguindo as deliberações da Conferência Episcopal Latino Americana de Medellín, a Prelazia de São Félix do Araguaia passou a ser uma espécie de laboratório, estabelecendo a este prelado como foco principal os mesmos princípios estabelecidos na Conferência, que consistia na opção pelos pobres, na reorganização das pastorais e comunidades de base para promoção humana, na dignidade pessoal do homem e, na ajuda mútua (ANGELOZZI, 2017, p. 117). Tais fatos podem ser evidenciados na celebração de 20 anos de caminhada da Igreja no norte Araguaia em que Pedro Casaldáliga escrevia aos fiéis da Prelazia:

O povo que habitava nestas bandas era quase todo Povo indígena até os anos $30[\ldots]$ a partir, foram chegando nortistas, nordestinos [...]. Eram os sertanejos posseiros. As grandes fazendas que aqui se abriam - desmatando e muitas vezes matando -arrebanharam milhares de peões. No meio desse povo foi estabelecida a Igreja local de São Félix do Araguaia. Para evangelizar esse Povo o Espirito a criou. Desse Povo ela devia cuidar, à luz da fé e com as armas do Evangelho. E nesta missão, que tanto exigia a celebração da missa como o atendimento da saúde e a educação, a administração do batismo e a luta pela terra, nossa Igreja, a Prelazia, entrou em conflito com os poderosos da região, do estado, do país. O latifúndio e seus pistoleiros, o estado e sua polícia, a ditadura militar e suas forças de segurança ou do exército, caíram em cima de nós e em cima do povo. Foi o tempo da grande repressão, a hora dura e bonita do martírio, (CASALDÁLIGA, 1990, p. 2).

A tomada de decisão, de lutar por condições de trabalho digno e contra a concentração excludente de terras, lhes renderam ao mesmo tempo admiração, respeito, esperança, complacência e resiliência dos pobres oprimidos, assim como ódio, ira, amargura, fragmentação e vingança dos opressores e seus fiéis defensores. Tais ações exigiam desta Prelazia e principalmente de Pedro Casaldáliga novas práticas pastorais, novos comportamentos e, isto ficou nítido no rompimento com "os poderosos" do Araguaia, assim como no distanciamento e na crítica ao regime autoritário em curso no Brasil. No auge das disputas pelo bem maior, que é a terra, a Igreja do Araguaia fortaleceu sua identidade como a Igreja dos oprimidos da terra.

Já havíamos cortado relações com as fazendas. Não podíamos celebrar a Eucaristia à sombra dos poderosos senhores, viajando em seus carros ou aviões, comendo ou bebendo uísque em sua mesa, sendo 'assistidos' nas celebrações pelos que escravizam sistematicamente os irmãos menores; essa 
já não seria a Ceia do Senhor!. Deixávamos de ser amigos dos grandes e os enfrentávamos. Nenhum explorador ou colaborador usado pela exploração poderia ser padrinho de batismo, por exemplo, (CASALDÁLIGA, 1979, p. $36)$.

Esta nova postura da equipe pastoral da Prelazia de São Félix do Araguaia, de certa forma influenciou o Clero a providenciar em regime de extrema urgência a nunciatura de um Bispo para este prelado. Foi, porém, D. Tomás de Balduino, Bispo de Goiás, que após comunicação em confidencialidade à Pedro Casaldáliga - respeitando o pedido de consulta da equipe desta Pastoral - o responsável por anunciar ao povo e conceder o rito de ordenação, que - diga-se de passagem - aconteceu às margens do rio Araguaia.

O primeiro ato de Pedro Casaldáliga como Bispo foi distribuir documentos em diversos meios de comunicação e por todas comunidades do norte Araguaia, anunciando a posição sóciopolítica da Igreja do Araguaia e denunciando às barbáries neste território. Os primeiros documentos do Bispo publicado na carta pastoral foram intitulados: "Uma Igreja na Amazônia em Conflito com o Latifúndio e Marginalização Social" e, "Escravidão e Feudalismo no Norte do Mato Grosso". Casaldáliga $(1971$, p. 1) afirmava que se "a primeira missão do Bispo é a de ser profeta" e “o profeta é a voz daqueles que não têm voz" (card. Marty), não poderia, honestamente, ficar de boca calada ao receber a plenitude do serviço sacerdotal.

A Carta Pastoral, resultante do trabalho coletivo dos agentes deste prelado e, de autoria do Bispo Pedro Casaldáliga apresenta uma descrição geográfica da área que compõe a Prelazia de São Félix do Araguaia, a origem e a distribuição populacional, diferentes formas de exploração da terra, os financiamentos das grandes fazendas, o regime de peonagem, os conflitos, a exploração da força de trabalho, a escravidão, a pobreza reinante, a ausência do Estado.

A Igreja do Araguaia, seguindo orientações da CNBB e da vocação à Teologia da Libertação, coordenada pelo bispo Pedro Casaldáliga, organizou sua equipe pastoral composta por padres, freiras e leigos, em várias frentes de atuação junto aos oprimidos, em defesa do que se entendia por direito de uso da terra. Segundo Escribano (2014, p. 34) "as campanhas missionárias que Casaldáliga planejou [...] consistiam em três meses de uma equipe num povoado do sertão, para de lá irradiar na área rural adjacente”. As atividades sempre inseridas dentro de encontros religiosos com finalidade de descobrirem líderes naturais, combinavam alfabetização de adultos, assistência à saúde e dinâmicas associativas. Para Escribano (2014, p. 34) o objetivo das incursões religiosas nos povoados consistia em criar comunidades de base a partir do lugar de sua respectiva atuação. 
As iniciativas que incentivavam camponeses e comunidades tradicionais a lutarem pelo direito de permanecerem na terra e dela tirarem sua sobrevivência, ao mesmo tempo desafiavam o latifúndio, seus projetos de expansão, e certamente o estado e seus representantes oficiais, que as entendiam como ações subversivas. A pastoral da Prelazia de São Félix do Araguaia nas comunidades camponesas representava - a partir de um entendimento da conjuntura política uma certa rebeldia e implicava nos agentes da ditadura militar uma interpretação de autêntica manobra de agitação política subversiva, (ESCRIBANO, 2014, p. 14).

Com o advento de financeirização do latifúndio pelo governo o número de grandes propriedades na Amazônia aumentou significativamente. Consequentemente ampliou os conflitos em todo território do norte Araguaia, onde posseiros e indígenas se tornaram vítimas de uma luta desigual pelo bem maior que é a terra. Tal decisão do estado em financiar a grande propriedade em detrimento da pequena implicou em duas situações que facilmente podem ser identificadas: a primeira consiste no apoderamento do Estado para defesa da propriedade privada e seus donatários; a segunda, compreende a sujeição dos trabalhadores da terra ao processo de expropriação e proletarização mediante ao avanço do capitalismo na agricultura, no Brasil.

A Comissão Pastoral da Terra (CPT), criada no ano de 1975 e atuante no território da Prelazia de São Félix do Araguaia, juntamente com o Bispo Pedro Casaldáliga e toda equipe de prelados (padres, freiras e leigos), constituíram a principal expressão política e ideológica dos oprimidos e vítimas dos conflitos pela terra, no norte Araguaia. Sua criação compreende uma resposta às graves situações vividas pelos trabalhadores rurais, posseiros, peões, sobretudo na Amazônia, explorados em seu trabalho, submetidos a condições análogas ao trabalho escravo e expulsos das terras que ocupavam.

Um fato semelhante e contemporâneo à situação ocorrida no território da Prelazia de São Félix do Araguaia, compreende a trajetória política de Pe. Josimo na região do Bico do Papagaio, no estado do Tocantins. Esta liderança religiosa foi protagonista da luta camponesa pela terra. Lira \& Santos (2017), descrevem a situação desta região em que suas principais vítimas foram despossuídas das propriedades de terra e, não aceitando tais imposições, iniciaram contestações das relações de poder. Para eles, o papel resguardado dos agentes pastorais é de questionar às condições ilegítimas de aquisição de terras e, evidenciar às crueldades dos grandes fazendeiros.

A atuação da CPT junto aos camponeses ocorria em momento coincidente as celebrações de missa nos povoados realizados ora pelo Bispo Pedro Casaldáliga, ora por outros padres que compunha esta pastoral. Ao término das celebrações os agentes pastorais se 
interagiram com a comunidade acolhendo todos os problemas, principalmente no que trata de questões agrárias, sobretudo às de conflitos. Suas responsabilidades enquanto agentes pastorais consistiam em conceder orientações que permitissem almejar a permanência das famílias na terra, ou, que permitisse ter dignidade no trabalho remunerado para aqueles que trabalhavam nesse regime.

A opção da Igreja do Araguaia para com a evangelização libertadora dos pobres e oprimidos da terra, fruto da contestação da realidade local vivenciada, colocava (e ainda coloca) todos os agentes desta pastoral em desacordo com o latifúndio e seus representantes. Casaldáliga (1971, p. 7) anunciava que em se tratando dos fazendeiros, gerentes e administrativos das grandes propriedades a ação pastoral era praticamente impossível, sempre que não aceitavam o poder de opressão social que o latifúndio encarnava. Para este pensador religioso "ajudar na libertação dos oprimidos é o meio mais direto e eficaz de contribuir para a libertação do opressor”.

\section{A luta efetiva}

Em São Félix do Araguaia diversos conflitos marcaram a história dos camponeses posseiros e comunidades tradicionais que habitam esta parcela do território norte Araguaia desde ainda a primeira metade do século XX. Para os objetivos deste artigo dois são importantes para compreender o movimento de resistência na luta pela terra. O primeiro, trata-se do povoado de Pontinópolis. O conflito agrário relevante deste povoado inicia-se na primeira metade da década de 1960, momento de criação da Agropecuária Suiá-Missú, de propriedade do senhor Ariosto Riva (CASALDÁLIGA, 1971, p. 14). Na época da abertura deste latifúndio residiam cerca de 300 famílias de camponeses posseiros em proximidade deste povoado anunciado. Uma parcela significativa da etnia Xavante também ocupava o território que estava sendo apropriado pelo latifúndio.

No primeiro momento, Ariosto Riva, proprietário do latifúndio em formação tratou de encontrar mecanismos de retirar deste território os tais "ocupantes". Os dirigentes articularam para inicialmente criar um clima de paz a fim de não transparecer o projeto em andamento, até mesmo porque necessitavam de mão de obra para as primeiras aberturas do latifúndio. Esta situação foi determinante para que o dono da agropecuária permitisse que as famílias camponesas posseiras de Pontinópolis permanecessem nas suas unidades produtivas, explorando as suas respectivas posses, porém com o dispêndio de empregar percentual ou total força de trabalho no grande latifúndio. 
Na segunda metade da década de 1960, após aprovado projeto de exploração da grande área junto à Superintendência de Desenvolvimento da Amazônia (SUDAM), o proprietário decidiu expulsar os camponeses e suas respectivas famílias, com aparato policial e pistolagem (o lema era: "sair ou morrer") e, empregar trabalhadores em regime de peonagem, oriundos de diferentes regiões do Brasil, mas, principalmente da região Nordeste, (CASALDÁLIGA, 1971, p. 14).

Pedro Casaldáliga e diversos agentes pastorais atuaram diretamente junto aos camponeses posseiros do povoado de Pontinópolis, orientando quanto aos direitos de uso da terra, fortalecendo neles suas identidades camponesas, o espírito de resistência e luta para permanecerem nas áreas que exploravam por décadas. Tais camponeses, já organizados, decidiram recorrer as autoridades competentes. Elegeram dois camponeses - o senhor José Antônio dos Santos e Antônio Batista dos Santos - para procurarem o órgão do governo federal em Cuiabá, responsável pelas terras ocupadas. Tratava-se do Instituto Nacional de Desenvolvimento Agrário (INDA) que na época recebeu a denúncia e interviu junto ao sr. Ariosto Riva para destinação de 15.000 hectares de terras o que compreenderia às áreas ocupadas pelos camponeses posseiros próximas ao povoado de Pontinópolis (CASALDÁliGA, 1971, p. 14).

Contrariando às deliberações do INDA, Ariosto Riva demarcou 15.000 hectares em outra área da grande fazenda, longe das unidades produtivas e do povoado Pontinópolis. Uma área com predominância do bioma Cerrado e varjão (na estação seca tem características de cerrado aberto, mas durante a estação chuvosa transforma-se em pradarias de vegetação flutuante), com demanda maior do emprego de força de trabalho familiar e certo isolamento geográfico. Tal situação gerou um desconforto para muitos que decidiram abandonar suas unidades produtivas e migrar para outros lugares, a procura de uma outra terra em que pudesse reproduzir sua unidade familiar.

Diante desse cenário, o papel importante desenvolvido pelos agentes da pastoral e sobretudo por Pedro Casaldáliga tornou a grande maioria destes camponeses motivados para permanecerem onde já estavam à décadas, mesmo sobre fortes pressões por parte dos representantes do latifúndio. As pressões sempre motivadas por violência de alto grau e até morte. Estes episódios persistiram até que a prelazia de São Félix do Araguaia se fez ouvida pelas instituições estatais assegurando, conforme determinado, a permanência das famílias camponesas no local de origem.

Outra situação de conflito agrário no município de São Félix do Araguaia de grande relevância para dinâmica territorial do norte Araguaia consiste ainda sob o mesmo latifúndio 
Suiá-Missú. A parte que nos interessa em descrever trata-se do território indígena ocupado primeiramente pela comunidade tradicional indígena de etnia Xavante, que tive o território grilado e anexado ao latifúndio. Toda população indígena que sobreviveu as moléstias e epidemias pelo contato com não indígenas foi expulsa e dirigida para Missão Salesiana de São Marcos, próximo à sede do município de Barra do Garças.

Para que tais ações se realizasse o governo militar, na década de 1960, disponibilizou para o dono do latifúndio Suiá-Missú aviões da Força Aérea Brasileira (FAB). A Igreja Católica, por sua vez, participou efetivamente do projeto de concentração fundiária disponibilizando os missionários salesianos que já atuavam no território em regime de evangelização e de desobriga para facilitar o convencimento dos Xavante que manifestava resistência às transferências em curso. Assim, esta força tarefa foi essencial para que toda área estivesse desocupada desta população e pronta para os projetos do latifúndio.

As estratégias de transferência iam para além destas ações. Portanto, os efetivos ataques de pistoleiros aos Xavante, em diferentes aldeias à mando dos gerentes do latifúndio e, a uma falsa "proteção" oferecida aos índios pelo dono da agropecuária possibilitaram um pseudo aldeamento que foi localizado ao lado da sede da fazenda. Tal situação disseminou moléstias e sucessivas mortes, essenciais para convencimento da necessidade de transferência de toda etnia indígena para outros territórios. Desta maneira, os sobreviventes indígenas foram distanciados cerca de $500 \mathrm{Km}$ de seu território para áreas de missões salesianas, o que permitiu a consolidação deste latifúndio.

No final da década de 1970, os domínios do latifúndio foi transferido, após compra e venda para Companhia Geral Italiana de Petróleo (AGIP). Os contínuos estímulos fisscais e financeiros por parte da Sudam possibilitou a exploração intensa, principalmente para fins extrativista e criação bovina extensiva. No processo de redemocratização do Brasil, em meados da década de 1980 houve interrupção destes investimentos por parte do governo, o que de certa forma mudou o rumo dos interesses do grupo Agip, principalmente no que confere a continuidade de investimentos em atividades primárias. Esta situação reafirma o interesse pela companhia em captação de recursos financeiros estatais para outros fins.

No início da década de 1990 o grupo Agip passou por intensos questionamentos principalmente de ordem ambiental e social. Na Conferência das Nações Unidas sobre o Meio Ambiente e Desenvolvimento (CNUMAD), também conhecida como Eco 92, ocorrida no Rio de Janeiro em 1992, sob pressões diversas, este grupo se comprometeu, mediante indenização do governo federal, na devolução de aproximados 160.000 hectares do grande latifúndio Suiá- 
Missú aos índios da etnia Xavante. O problema estaria próximo de ser resolvido pois tanto o governo federal quanto o grupo Agip haviam se comprometido nesta Conferência.

No entanto, um grupo de ex-administradores e gerentes da Suiá-Missú descontentes da decisão de fracionamento deste latifúndio, e da devolução de aproximados 160.000 hectares de terras para formação da reserva indígena Marãiwatsédé associaram-se à grileiros e atravessadores de terras e decidiram incentivar diversas famílias camponesas que encontravamse expropriadas do direito de posse e de propriedade, para ocupação principalmente da área destinada aos Xavante. A morosidade jurídica favoreceu tal acontecimento.

A Prelazia de São Félix do Araguaia, a CPT e, sobretudo o Bispo Pedro Casaldáliga tentaram insistentemente alertar quanto a sobreposição de uso do território. Porém, ações governamentais equivocadas acabaram por permitir a ocupação e apropriação da terra indígena Marãiwatsédé. Tais ações compreendiam a grilagem, a falsificação de títulos de domínio e, a demarcação de médias e grandes propriedades comercializáveis por parte de um grupo de exfuncionários administrativos do latifúndio Suiá-Missú e de médios comerciantes regionais. Concomitante a este movimento de grilagem os camponeses posseiros que se encontravam na condição de sem-terra foram incentivados a ocupar parte desta área e delimitar suas unidades produtivas.

Ao mesmo tempo, o estado realizou abertura de estradas vicinais, distribuição de redes de eletrificação rural, disponibilização de linhas de créditos, efetivação de projetos de habitação, escolas e posto de saúde. Fruto desta dinâmica produtiva compreende o núcleo urbano denominado Estrela do Araguaia, além de várias associações de produtores da agricultura e de criadores da pecuária.

Estas ações governamentais equivocada, associada com a morosidade da justiça para devolução definitiva dos direitos de domínio da reserva indígena Marãiwatsédé criou no imaginário, principalmente dos camponeses, uma quase "certeza" de direito constituído pela exploração de suas unidades produtivas. Foram vinte anos de ocupação no seio da unidade coletiva. Foram exatamente esse mesmo tempo de permanência orquestrados ora por subsídios do governo federal, ora pelos excedentes comercializáveis da unidade familiar. Corresponde o equivalente tempo desprendido pelas famílias camponesas no que entendiam como terra de trabalho e, por isso, a compreensão da possibilidade de permanência, de exploração, de resistência da sua unidade familiar. E, certamente é por essas situações que Martins (1993, p. 45) contextualiza: "a luta do posseiro introduz uma legitimidade alternativa da posse, contornando a legalidade da propriedade". 
Porém, em 2012 aconteceu na cidade do Rio de Janeiro a Conferência das Nações Unidas sobre Desenvolvimento Sustentável (CNUDS), também conhecida como Rio + 20. As deliberações dali tomada, de certo modo, pressionaram a justiça quanto a devolução da terra indígena Marãiwatsédé. Esta ação certamente garantiria a legalidade do território indígena contrariando a legitimidade da posse dos camponeses. No início de janeiro de 2013 o governo federal decidiu cumprir a decisão judicial e, procedeu para desintrusão da respectivas terra, porém com o dispêndio de expulsar camponeses e médios produtores que faziam uso deste território em litígio, o que significa dizer, a desapropriação da desapropriação.

\section{Considerações finais}

Em virtude do que foi mencionado, pode-se afirmar que o campesinato enquanto ator de sua própria história coloca-se como um elemento essencial para a estruturação das mais variadas formações econômicas no tempo e no espaço. Assim, verificou-se que essa classe social, além de se figurar como tal, significa também um modo de vida, cujas características principais são a ligação direta com a terra e a produção baseada na organização familiar. O camponês não precisa explorar a força de trabalho alheia para que a sua reprodução seja assegurada, no entanto, explora apenas a si mesmo; desse modo, a sua satisfação material está condicionada ao nível de fadiga ao qual está submetido.

A ocupação do território promovida pela expansão do modo de vida camponês se figura como uma realidade histórica num país como o Brasil, cujas dimensões são enormes. Os posseiros que outrora ocuparam inicialmente a região do norte Araguaia são uma prova viva desse quadro; o campesinato brasileiro, como ficou claro, luta para entrar e permanecer na terra, e contraditoriamente é expulso e reinserido nesta. O conflito pelo uso da terra se torna uma realidade frenética, uma vez que essa dádiva da natureza é a fonte de toda prosperidade social. A terra não tem valor, pois não é produto do trabalho humano, mas o seu uso pode ser capaz de produzir uma riqueza inestimável para sociedade como um todo; ela é senão a base material da reprodução da vida imediata de toda sociedade.

A região da Prelazia de São Félix do Araguaia marca essa discussão, os conflitos entre o campesinato e a concentração fundiária típica da nossa formação econômica se faz presente naquela parcela do território. Nesse país marcado pelas desigualdades socioeconômicas, a luta

pela terra se configura como uma das mais emblemáticas questões a ser analisada. A persistência do campesinato deriva da sua íntima ligação com a terra; essa ligação extrapola os 
limites da lógica produtiva alcançando os laços culturais e políticos que faz dessa classe um modo de vida.

Desse modo, a luta camponesa que se faz presente no território da Prelazia de São Félix do Araguaia mostra o caráter eminentemente histórico da luta de classes no Brasil. Os interesses dos grupos entram em choque, pois são antagônicos por natureza; assim, o papel de um bispo como Dom Pedro Casaldáliga se torna imprescindível no tocante aos conflitos naquela região. O seu papel ativo nesse processo marca a ruptura de alguns membros da Igreja Católica com as concepções tradicionais até então reinantes na Cúria Romana. A sua atividade militante o fez virar uma grande referência nacional no que diz respeito à problemática dos conflitos agrários, bem como do envolvimento da igreja nessas questões.

Assim, pode-se concluir que a luta camponesa no último quartel do século passado neste território da Amazônia assumiu novas tessituras, sobretudo devido às concepções da Teologia da Libertação em ascensão. Essa parceria entre o campesinato e o movimento religioso libertário no estudo de caso aqui apresentado obteve êxito diante das dificuldades apresentadas durante o processo de luta pela terra. Portanto, o debate aqui exposto visa ser uma contribuição para a geografia agrária como um todo, mas especificamente para os segmentos que trabalham as questões da luta campesina e o movimento da Teologia da Libertação.

\section{Referências}

ANDRADE, M. C. de. A Questão do Território no Brasil. São Paulo: Hucitec, 2004.

ANGELOZZI, G. A. Igreja, Estado e Poder: as relações entre Igreja e do Estado no Brasil. Jundiaí. - Paco Editorial, 2017.

BANDECCHI, Brasil. Origem do Latifúndio no Brasil. São Paulo: Editora Fulgor Limitada, 1963.

\section{CASALDÁLIGA, P. Uma igreja na Amazônia em conflito com o latifúndio e a marginalização social. São Félix do Araguaia: Carta Pastoral, 1971.}

Eu creio na Justiça e na Esperança. Rio de Janeiro: Civilização Brasileira, 1979.

Nossa Igreja. Jornal Alvorada. São Félix do Araguaia, julho/agosto/1990, p. 2.

12.

. Histórica resistência. Jornal Alvorada. São Félix do Araguaia, março/abril/1997, p.

Quando os Dias fazem pensar; memória, ideário, compromisso. São Paulo:

Paulinas, 2007.

ESCRIBANO, F. Descalço sobre a terra vermelha: A vida do bispo Pedro Casaldáliga. -

$2^{\mathrm{a}}$ ed. Campinas, SP: Editora da Unicamp, 2014. 
FELICIANO, C. A. Estado, apropriação e concentração de terra e poder: da propriedade como direito natural ao questionamento da função social da terra, in: (orgs) Miditiero Júnior, M. A.; GARCIA, M. F.; VIANA, P. C. G. A questão agrária no século XXI: escalas, dinâmicas e conflitos territoriais - $1^{\mathrm{a}}$ ed. - São Paulo: Outras Expressões, 2015.

GUIMARÃES, A. Formação da Pequena Propriedade: intrusos e posseiros (1963). In: WELCH, Clifford Andrew et al (Orgs.). Camponeses Brasileiros: leituras e interpretações clássicas, v.1. São Paulo: Editora UNESP; Brasília, DF: Núcleo de Estudos Agrários e Desenvolvimento Rural, 2009.

IANNI, O. A Luta pela terra: história social da terra e da luta numa área da Amazônia. - Petrópolis: Vozes, 1979.

JAHNEL, T. C. As leis de terras no Brasil. Boletim Paulista de Geografia, n 65, São Paulo, p. $105-115,1987$.

LIMA FILHO, M. F. Pioneiros da Marcha para o Oeste: memória e identidade na fronteira do médio Araguaia. 1998. 282f. Tese (Doutorado em Antropologia Social) - Universidade Nacional de Brasília, Brasília, 1998.

LOWY, M. O que é Cristianismo da Libertação: religião e política na América Latina. $2^{\mathrm{a}}$ ed. - São Paulo: Editora Fundação Perseu Abramo: Expressão Popular, 2016.

MARTINS, J. S. A chegada do estranho. São Paulo: Editora Hucitec, 1993.

Os Camponeses e a Política Pública no Brasil: as lutas sociais no campo e seu lugar no processo político. Petrópolis: Vozes, 1995. 2014

Fronteira: a degradação do Outro nos confins do humano. São Paulo: Contexto,

SANTOS, G.; LIRA, E. R. Padre Josimo e Mulheres em Movimento no Bico do Papagaio: o esforço teórico - uma síntese para entender um novo protagonismo na luta pela terra. In: SANTOS, Roberto de Souza; LIRA, Elizeu Ribeiro. (Orgs.). Fronteira, Território e Cidades no Cerrado: discussões e reflexões socioterritoriais. Goiânia: Kelps, 2017. 